\title{
Extension of New Zealand kauri (Agathis australis) tree-ring chronologies into Oxygen Isotope Stage (OIS) 3
}

\author{
JONATHAN PALMER, ${ }^{1 *}$ ANDREW LORREY, ${ }^{2}$ CHRIS S. M. TURNEY, ${ }^{3}$ ALAN HOGG ${ }^{4}$ MIKE BAILLIE, ${ }^{5}$ KEITH FIFIELD ${ }^{6}$ and \\ JOHN OGDEN ${ }^{2}$ \\ ${ }^{1}$ PO Box 14, Little River, Canterbury 8162, New Zealand \\ ${ }^{2}$ School of Geography and Environmental Science, The University of Auckland, Auckland, New Zealand \\ ${ }^{3}$ School of Earth and Environmental Sciences, University of Wollongong, Wollongong, New South Wales, Australia \\ ${ }^{4}$ Radiocarbon Dating Laboratory, University of Waikato, Hamilton, New Zealand \\ ${ }^{5}$ School of Geography and Archaeology, Queens University Belfast, Northern Ireland, UK \\ ${ }^{6}$ Department of Nuclear Physics, Research School of Physical Sciences and Engineering, Australian National University, ACT, \\ Australia
}

\begin{abstract}
New Zealand kauri (Agathis australis) is both long-lived and sensitive to climate so during the past two decades an extensive network of sites has been sampled for dendrochronological analyses. The network can be divided into three general groups based on the time period they cover'modern' kauri (MK), late-Holocene kauri (HK) and 'ancient' kauri (AK) from before the Last Glacial Maximum (LGM). Although the groups are restricted to northern New Zealand (i.e. having overlapping ranges) they occur at different elevations. Modern kauri sites tend to be along ridges and much higher than the two subfossil groups (i.e. HK and AK sites). We propose the modern kauri situation to be a typical artefact of anthropogenic activities. In contrast, the subfossil groups are the result of a complex process of dune migration, levee formation and water-table rise leading to bog formation driven by rising sea levels. Most of the 16 AK sites have radiocarbon ages clearly within Oxygen Isotope Stage (OIS) 3 and a preliminary group of chronologies have been developed that collectively cover $10719 \mathrm{yr}$. Analysis is ongoing, but there is clear potential to span a much greater time period and recover detailed palaeoclimatic information. Copyright (C) 2006 John Wiley \& Sons, Ltd.
\end{abstract}

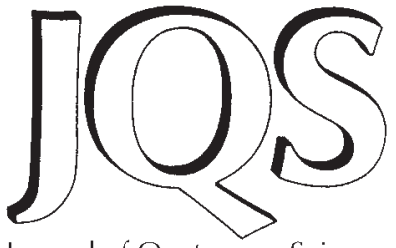

Journal of Quaternary Science

KEYWORDS: dendrochronology; Agathis australis; tree-rings; OIS 3; New Zealand

\section{Introduction}

Although loosely termed as 'warm' by the isotopic nomenclature, Oxygen Isotope Stage (OIS) 3, spanning the period 25000 to $60000 \mathrm{yr}$ ago (25-60 ka), was a period of exceptional climatic variability during the late Quaternary. Within the North Atlantic region, OIS 3 was characterised by a series of rapid $\left(<10^{2} \mathrm{yr}\right)$ and severe $\left(10^{1} 1 / 2 \mathrm{C}\right)$ millennial-scale climatic oscillations referred to as Dansgaard-Oeschger (D-O) events that have been identified in oceanic, ice and terrestrial records throughout the Northern Hemisphere (Voelker et al., 2002). These D-O events can be bundled into regular, decreasing amplitude, cooling cycles as asymmetrical 'sawtooth' shapes (Bond Cycles; Bond et al., 1993) that culminated in massive discharges of ice into the North Atlantic, of which the most

* Correspondence to: J. Palmer, PO Box 14, Little River, Canterbury 8162, New Zealand. E-mail: palmerama@paradise.net.nz prominent are the so-called Heinrich events. The exact timing, magnitude and global extent of these events are currently uncertain (Sarnthein et al., 2002), limiting our understanding of how rapid, extreme climate shifts are propagated around the world, particularly to Australasia.

A review of centennial-scale records from marine, ice-core and terrestrial sites for OIS 3 by Voelker et al. (2002) highlighted the bias in the spatial database towards the Northern Hemisphere. Marine records were also nearly twice as abundant as the ice-core and terrestrial sites combined. Their conclusion was that more records are needed, especially from the Southern Hemisphere. Of the 183 sites listed from the latter, only one was derived using tree-ring widths (with none in the Northern Hemisphere). This key site is located in northern Patagonia, Chile, where 28 Fitzroya cupressoides trees produced a 1229-yr floating chronology (Roig et al., 2001) dated at around 50000 ${ }^{14} \mathrm{C}$ yr BP. The position and orientation of the stumps suggested that the trees in this chronology were overwhelmed by a lahar (i.e. a catastrophic single event). Their discovery was a result of a recent earthquake that subsequently exposed the subfossil 
F. cupressoides stumps, suggesting little chance of developing a continuous record through all of OIS 3 from that region.

The development of high-resolution tree-ring chronologies in the mid-latitudes is crucial if we are to test hypotheses of interhemispheric synchroneity of climate change during OIS 3. The variation in tree-ring widths from one year to the next is widely recognised as an important source of accurate palaeoclimatic information (Bradley, 1999). Historically, the research focus for dendroclimatology has been in mid- to high-latitudes (e.g. Fritts, 1976; Briffa and Matthews, 2002; Cook et al., 2004) though this is extending towards the tropics (D'Arrigo et al., 2006). In the ocean-dominated Southern Hemisphere, relatively few tree-ring chronologies have even been developed for the Holocene (Jones et al., 2001) though Cook et al. (2006) (this issue) describe substantial progress towards providing reliable dendroclimatic records in the Australasian region. Around 100 tree-ring chronologies have been developed from seven native conifer species and three angiosperms in New Zealand since the late 1970s at sites across the country (ITRDB, 2004; Norton and Ogden, 1987). Most tree-ring chronologies from New Zealand, however, span less than $500 \mathrm{yr}$ in length.

Kauri (Agathis australis) is both long-lived (over $500 \mathrm{yr}$; Ogden, 1983) and sensitive to climate (Ogden and Ahmed, 1989; Fowler et al., 2000). Agathis australis is an evergreen conifer within the family Araucariaceae which has several tropical species. Agathis is spread along the western edge of the Pacific with kauri being the southernmost representative and the only Araucariaceae endemic to New Zealand (Salmon, 1980). It is a large canopy-emergent tree that reaches heights exceeding $30 \mathrm{~m}$ with some living specimens having diameters greater than $5 \mathrm{~m}$ (Sale, 1978). The dendroclimatic potential of kauri has been recognised since Dunwiddie (1979) first produced a tree-ring chronology. Since then, a network of 17 chronologies from modern kauri sites has gradually been developed (Buckley et al., 2000; Fowler et al., 2000, 2004) and recently linked to late Holocene (subfossil) material extracted from bog sites (Boswijk et al., 2006; see also Cook et al., this issue).

In this paper, we will consider the data under three headings: (1) 'modern kauri' (MK): trees that were living at the time of sample collection (increment cores) - the dimensions of the tree and its location on the landscape are known; (2) 'Holocene kauri' (HK): timber collected from bogs of late Holocene age; and (3) 'ancient kauri' (AK): wood from bogs of before the Last Glacial Maximum age-most belongs to OIS 3, but some probably relates to earlier interstadial or interglacial periods (e.g. OIS 5). Here we report on the development of AK sites from OIS 3 and compare them to modern and late Holocene kauri data already published.

\section{New Zealand kauri collections}

\section{Modern kauri (MK) sites (Table 1(a))}

Living kauri trees are found predominantly on ridges and northfacing slopes at elevations between sea level and ca. $600 \mathrm{~m}$, from the far north of New Zealand southwards to Kawhia (approximately $34-38^{\circ} \mathrm{S}$; Poole and Adams, 1986) (Fig. 1). Modern kauri stands rarely border swamps or bogs, although the present pattern is largely an artefact of Polynesian burning (McGlone, 1983; Ogden et al., 1998) and European logging from the 1870s to the 1930s (Reed, 1964; Halkett and Sale, 1986). The pre-logging distribution is not known in detail, but it was certainly more common in the lowlands than at present. Seventeen modern kauri chronologies are summarised in
Table 1(a). Sites range in altitude between $630 \mathrm{~m}$ and $90 \mathrm{~m}$, with a mean of $280 \pm 135 \mathrm{~m}$. As expected, the average ringwidth of sites at higher elevation is smaller than those at lower elevation. The overall average ring-width (ARW) was $1.66 \pm 0.59 \mathrm{~mm} \mathrm{yr}^{-1}$. This is similar to the rate of $1.57 \pm 0.21 \mathrm{~mm} \mathrm{yr}^{-1}$ determined by Ahmed and Ogden (1985). An important point to note is that these growth rates do not include trees unable to be cross-dated. Kauri is not an easy species to cross-date (because it has both false and missing rings) so an initial bias might be towards the faster-growing trees. This is supported by the quoted growth rate by Ahmed and Ogden (1985) for non-cross-dated series from 8 sites being $1.13 \pm 0.44 \mathrm{~mm} \mathrm{yr}^{-1}$. However, many of the cross-dated sites have been reassessed and updated so that our reported growth rate now includes a much larger number of series (240 compared with 131 trees). The increase is also a benefit of better cross-dating tools being available (e.g. Fowler et al., 2004) and has resulted in representation from the entire MK growing region.

\section{Holocene kauri (HK) sites (Table 1(b))}

The late-Holocene kauri logs are found in poorly drained lowland sites lying in peat, and scattered over a $200-\mathrm{km}$ stretch of northern New Zealand (Fig. 1). HK sites extend to the current southern limit of kauri in the Waikato (approximately $38^{\circ} \mathrm{S}$ ). Eleven chronologies described in detail by Boswijk et al. (2006) are listed by region in Table 1 (b). All the sites are situated close to modern sea level (range 5 to $15 \mathrm{~m}$ ) and the average ringwidth is less than those for modern kauri.

\section{OIS 3 'ancient kauri' (AK) sites (Table 1(c))}

The OIS 3 (AK) sites show geographical overlap with the Holocene (HK) sites, but are not found towards the southern limit, and extend further north onto the Aupouri Peninsula (i.e. $34^{\circ} 50^{\prime}-36^{\circ} 20^{\prime} \mathrm{S}$ ). Some of the buried trees are of enormous proportions, with diameters greater than $4 \mathrm{~m}$ and individual ages of more than $2000 \mathrm{yr}$. The remarkable preservation state of subfossil kauri (with bark often still intact; Fig. 2), coupled with renowned timber qualities (Clifton, 1994) and living tree protection from logging, has meant buried kauri (i.e. both HK and $\mathrm{AK}$ ) is a valuable resource. Consequently the wood is currently being 'harvested' for commercial purposes. This has resulted in an increasing rate of extraction although the resource is dwindling. Table 1(c) documents 16 sites from which chronologies have been obtained or which are currently under investigation.

A comparison of the three different collections (i.e. MK, HK and $A K$ ) in terms of their elevations and growth rates are summarised in Fig. 3. An intriguing observation is that there is virtually no overlap in the altitudinal range of the different types of sites (Table 1; Fig. 3). The modern sites are spread over a wide elevational range but are rarely near sea level whereas all the Holocene sites are close to sea level and the AK sites are consistently perched around $30 \mathrm{~m}$ higher (with the two eastern AK sites-OMA, MNG being the exceptions). Although the AK sites are at higher elevations than the HK sites, they are still in a lowland setting, with almost no altitudinal overlap with MK sites. The very slow average growth rates of some of the AK trees, maintained over several centuries are a notable feature of the data. Overall, however, the AK sites are not significantly different from the HK sites in average growth rates implying that 
Table 1 Summary of kauri (Agathis australis) collection sites

(a) Modern kauri (MK) sites

\begin{tabular}{|c|c|c|c|c|c|c|}
\hline Region & $\begin{array}{l}\text { Site } \\
\text { codes }\end{array}$ & $\begin{array}{l}\text { Chronology } \\
\text { length (yr) }\end{array}$ & $\begin{array}{l}\text { Elevation } \\
\text { (m a.s.I.) }\end{array}$ & No. trees & $\begin{array}{l}\text { Average ring-width } \\
\text { (ARW) (mm) }\end{array}$ & $\begin{array}{l}\text { Comments/references } \\
\text { (note: only the most recent } \\
\text { reference is quoted) }\end{array}$ \\
\hline \multirow[t]{5}{*}{ Northland } & PUBL, & 359 & 305 & 9 & $1.68 \pm 0.42$ & From Fowler et al. 2004 \\
\hline & PUKF, & 498 & 290 & 22 & $1.54 \pm 0.35$ & $\begin{array}{l}\text { From Fowler et al. 2004, } \\
\text { updated in Fowler et al. (in prep.) }\end{array}$ \\
\hline & WARA, & 339 & 468 & 14 & $1.43 \pm 0.48$ & From Fowler et al. 2004 \\
\hline & WAID, & 275 & 180 & 6 & $2.06 \pm 0.34$ & From Fowler et al. 2004 \\
\hline & TROU, & 473 & 175 & 26 & $1.65 \pm 0.39$ & $\begin{array}{l}\text { From Fowler et al. 2004, } \\
\text { updated in Fowler et al. (in prep.) }\end{array}$ \\
\hline \multirow[t]{6}{*}{ Auckland } & HUPI, & 514 & 90 & 36 & $1.47 \pm 0.37$ & From Fowler et al. 2004 \\
\hline & CASC, & 423 & 180 & 14 & $1.26 \pm 0.27$ & From Fowler et al. 2004 \\
\hline & HUIA, & 261 & 274 & 7 & $1.32 \pm 0.21$ & From Fowler et al. 2004 \\
\hline & WTDM, & 274 & 210 & 7 & $1.83 \pm 0.53$ & From Fowler et al. (in prep.) \\
\hline & KOND, & 206 & 335 & 10 & $1.82 \pm 0.41$ & From Fowler et al. 2004 \\
\hline & MWIL & 401 & 350 & 6 & $1.18 \pm 0.27$ & From Fowler et al. 2004 \\
\hline \multirow[t]{4}{*}{ Coromandel } & LTBR & 191 & 274 & 11 & $1.70 \pm 0.41$ & From Fowler et al. 2004 \\
\hline & HIDV, & 306 & 220 & 13 & $1.31 \pm 0.12$ & From Fowler et al. (in prep.) \\
\hline & MOEH, & 620 & 630 & 15 & $1.29 \pm 0.23$ & From Fowler et al. 2004 \\
\hline & MASC & 729 & 350 & 17 & $0.93 \pm 0.30$ & From Fowler et al. 2004 \\
\hline Waikato & KAWH & 286 & 80 & 10 & $2.54 \pm 0.64$ & From Fowler et al. 2004 \\
\hline Hawkes Bay & KATI & 298 & 350 & 17 & $2.36 \pm 0.71$ & From Fowler et al. 2004 \\
\hline Total/Average & 17 sites & $225 \pm 87$ & $280 \pm 135$ & 240 & $1.66 \pm 0.59$ & \\
\hline
\end{tabular}

(b) Holocene kauri (HK) sites

\begin{tabular}{|c|c|c|c|c|c|c|}
\hline Region & $\begin{array}{l}\text { Site } \\
\text { codes }\end{array}$ & $\begin{array}{l}\text { Maximum } \\
\text { chronology length }\end{array}$ & $\begin{array}{l}\text { Average elevation } \\
\text { (m a.s.l.) }\end{array}$ & No. trees & $\begin{array}{l}\text { Average ring-width } \\
\quad(\text { ARW })(\mathrm{mm})\end{array}$ & Comments/references \\
\hline \multirow{7}{*}{ Northland } & MAIT & 1003 & 10 & 9 & $0.91 \pm 0.19$ & From Boswijk et al. 2006 \\
\hline & HOAN, & 568 & 5 & 1 & 1.06 & From Boswijk et al. 2006 \\
\hline & YAKK, & 970 & 10 & 16 & $1.26 \pm 0.78$ & From Boswijk et al. 2006 \\
\hline & $\mathrm{CHIT}$ & 1319 & 10 & 15 & $1.17 \pm 0.32$ & From Boswijk et al. 2006 \\
\hline & HARD, & 1030 & 15 & 13 & $1.46 \pm 0.46$ & From Boswijk et al. 2006 \\
\hline & TIKI, & 664 & 5 & 1 & 0.87 & From Boswijk et al. 2006 \\
\hline & POUT & 575 & 5 & 1 & 1.48 & From Boswijk et al. 2006 \\
\hline \multirow[t]{3}{*}{ Waikato } & PUKE, & 803 & 10 & 15 & $1.12 \pm 0.34$ & From Boswijk et al. 2006 \\
\hline & WHAN, & 1050 & 10 & 34 & $1.33 \pm 0.46$ & From Boswijk et al. 2006 \\
\hline & FNSR & 1084 & 10 & 16 & $1.11 \pm 0.40$ & From Boswijk et al. 2006 \\
\hline Total/Average & 11 sites & $376 \pm 106$ & $9 \pm 3$ & 121 & $1.23 \pm 0.47$ & \\
\hline
\end{tabular}

(c) Subfossil kauri sites older than the Holocene (i.e. 'ancient kauri' —AK)

\begin{tabular}{|c|c|c|c|c|c|c|c|c|}
\hline Site & Code & $\begin{array}{l}\text { Lat. } \\
\text { (South) }\end{array}$ & $\begin{array}{l}\text { Long. } \\
\text { (East) }\end{array}$ & $\begin{array}{l}\text { Elevation } \\
\text { (m a.s.l.) }\end{array}$ & No. trees & $\begin{array}{c}\text { Average } \\
\text { ring-width (ARW) }\end{array}$ & $\begin{array}{l}\text { Radiocarbon } \\
\text { age }( \pm 1 \sigma)\end{array}$ & $\begin{array}{c}\text { Comments/references/ } \\
\text { radiocarbon } \\
\text { reference number }\end{array}$ \\
\hline
\end{tabular}

Northland

\begin{tabular}{|c|c|c|c|c|c|c|c|c|}
\hline Trig Road & TRIG & $34^{\circ} 47^{\prime}$ & $173^{\circ} 04^{\prime}$ & 30 & 11 & $1.05 \pm 0.29$ & $>35000$ & $\begin{array}{l}\text { Wk8442, } \\
\text { Ogden et al., } 1992\end{array}$ \\
\hline Wharemaru & WRU & $34^{\circ} 57^{\prime}$ & $173^{\circ} 12^{\prime}$ & 40 & 2 & - & $>40000$ & Wk13442 \\
\hline Vinac Farm & VIN & $34^{\circ} 59^{\prime}$ & $173^{\circ} 11^{\prime}$ & 40 & 10 & $1.41 \pm 0.52$ & $60300 \pm 640$ & $\begin{array}{l}\text { Wk14419-14427, } \\
\text { Hogg et al., } 2006\end{array}$ \\
\hline Dean Farm & DEAN & $35^{\circ} 01^{\prime}$ & $173^{\circ} 11^{\prime}$ & 40 & 2 & - & $>40000$ & Wk13337 \\
\hline Lake Ngatu & NGT & $35^{\circ} 02^{\prime}$ & $173^{\circ} 11^{\prime}$ & 30 & 7 & - & $\begin{array}{l}>40000 \\
>55000\end{array}$ & $\begin{array}{l}\text { Wk13443 } \\
\text { Wk16689 }\end{array}$ \\
\hline Stewart sawmill & STE & $35^{\circ} 02^{\prime}$ & $173^{\circ} 15^{\prime}$ & - & 3 & 1.85 & $\begin{array}{l}>50000 \\
>50000\end{array}$ & $\begin{array}{l}\text { Wk } 13906 \\
\text { Wk7075 }\end{array}$ \\
\hline Sweetwater Farm & SWT & $35^{\circ} 04^{\prime}$ & $173^{\circ} 11^{\prime}$ & 30 & 4 & - & $>55000$ & Wk14689 \\
\hline Duder Farm & DUD & $35^{\circ} 42^{\prime}$ & $173^{\circ} 32^{\prime}$ & 80 & 24 & $0.99 \pm 0.27$ & $\begin{array}{l}59700 \pm 590 \\
43800 \pm 720\end{array}$ & $\begin{array}{l}\text { Wk15590-92, } \\
\text { 15670-74, 15730-33 } \\
\text { Hogg et al., } \\
\text { 2006, ANUA33016 }\end{array}$ \\
\hline Bibby Farm & $\mathrm{BIB}$ & $35^{\circ} 42^{\prime}$ & $173^{\circ} 32^{\prime}$ & 80 & 6 & $1.33 \pm 0.38$ & $>55000$ & Wk5383 \\
\hline Roe Farm & ROE & $35^{\circ} 48^{\prime}$ & $173^{\circ} 38^{\prime}$ & 70 & 8 & $1.16 \pm 0.31$ & $>55000$ & ANUA33024 \\
\hline
\end{tabular}


Table 1 (Continued)

(c) Subfossil kauri sites older than the Holocene (i.e. 'ancient kauri' - AK)

\begin{tabular}{|c|c|c|c|c|c|c|c|c|}
\hline Site & Code & $\begin{array}{l}\text { Lat. } \\
\text { (South) }\end{array}$ & $\begin{array}{l}\text { Long. } \\
\text { (East) }\end{array}$ & $\begin{array}{l}\text { Elevation } \\
\text { (m a.s.l.) }\end{array}$ & No. trees & $\begin{array}{c}\text { Average } \\
\text { ring-width (ARW) }\end{array}$ & $\begin{array}{l}\text { Radiocarbon } \\
\text { age }( \pm 1 \sigma)\end{array}$ & $\begin{array}{c}\text { Comments/references/ } \\
\text { radiocarbon } \\
\text { reference number }\end{array}$ \\
\hline & & & & & & & $>40000$ & Wk13444 \\
\hline Don McLeod Farm & DMC & $35^{\circ} 49^{\prime}$ & $173^{\circ} 38^{\prime}$ & 90 & 8 & $1.05 \pm 0.35$ & No age available & Adjacent to Roe Farm \\
\hline Finlayson Farm & FIN & $35^{\circ} 50^{\prime}$ & $173^{\circ} 39^{\prime}$ & 80 & 13 & $0.99 \pm 0.38$ & $\begin{array}{c}27796 \pm 182 \\
46141 \pm 1398\end{array}$ & $\begin{array}{l}\text { Wk16711 } \\
\text { Wk16712 }\end{array}$ \\
\hline Coles Farm & $\mathrm{COL}$ & $36^{\circ} 06^{\prime}$ & $173^{\circ} 56^{\prime}$ & 30 & 2 & - & No age available & $\begin{array}{l}\text { Adjacent to } \\
\text { Randall Farm }\end{array}$ \\
\hline Randall Farm & RAN & $36^{\circ} 06^{\prime}$ & $173^{\circ} 56^{\prime}$ & 40 & 3 & - & $\begin{array}{l}1297 \pm 35 \\
>50000\end{array}$ & $\begin{array}{l}\text { Wk17808, } \\
\text { Two bog areas. } \\
\text { Wk17809 }\end{array}$ \\
\hline Mangawhai Heads & MNG & $36^{\circ} 08^{\prime}$ & $174^{\circ} 36^{\prime}$ & 15 & 9 & $1.20 \pm 0.45$ & 39500 & Wk17400 \\
\hline Omaha Flats & OMA & $36^{\circ} 18^{\prime}$ & $174^{\circ} 30^{\prime}$ & 15 & 55 & $1.46 \pm 0.46$ & $\begin{array}{c}28518 \pm 221 \\
>47330\end{array}$ & $\begin{array}{l}\text { Wk17551 } \\
\text { Wk17550 }\end{array}$ \\
\hline
\end{tabular}

the latter may form a useful analogue when considering the ecology of the bogs and the preservation of the wood.

Modern kauri sites were from higher elevations and fastergrowing than the other two types of collections. Normally, the expectation would be that lower-elevation sites are fastergrowing than those at higher elevations. Clearly this is not the case and there are several possible causes including temporal differences in climate, the difference in the segment length of the tree-ring series or habitat type (e.g. well-drained ridges compared with bog margins; Ogden et al., 1992). A difference in growth habitat would raise a uniformitarian issue if multimillennial climate reconstruction were attempted on the basis of MK trees and applied to the cross-dated HK sites (Fowler et al., 2004; Boswijk et al., 2006).

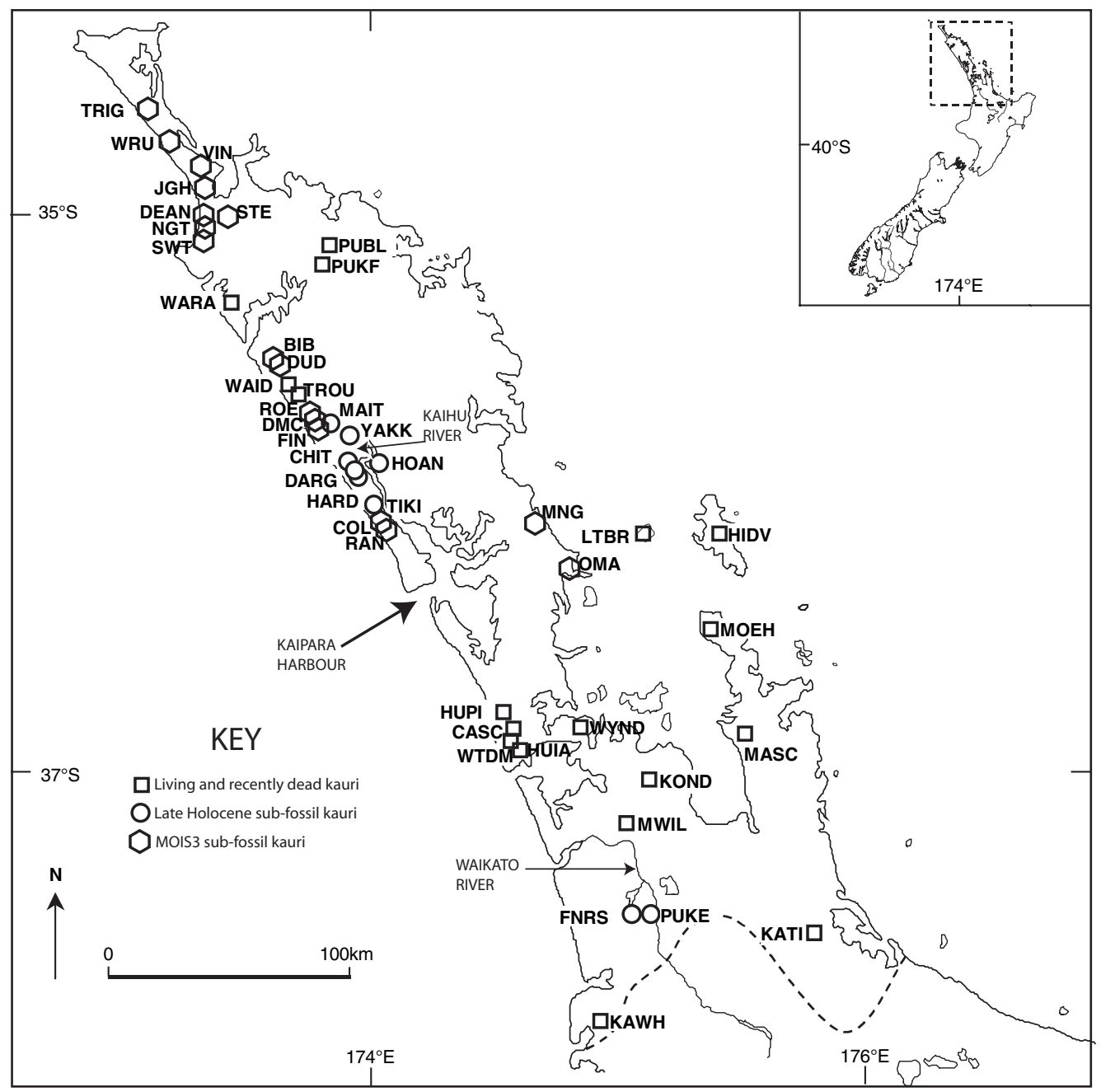

Figure 1 Location of kauri (Agathis australis) sites. Lettering represents sample site codes referred to in Table 1 


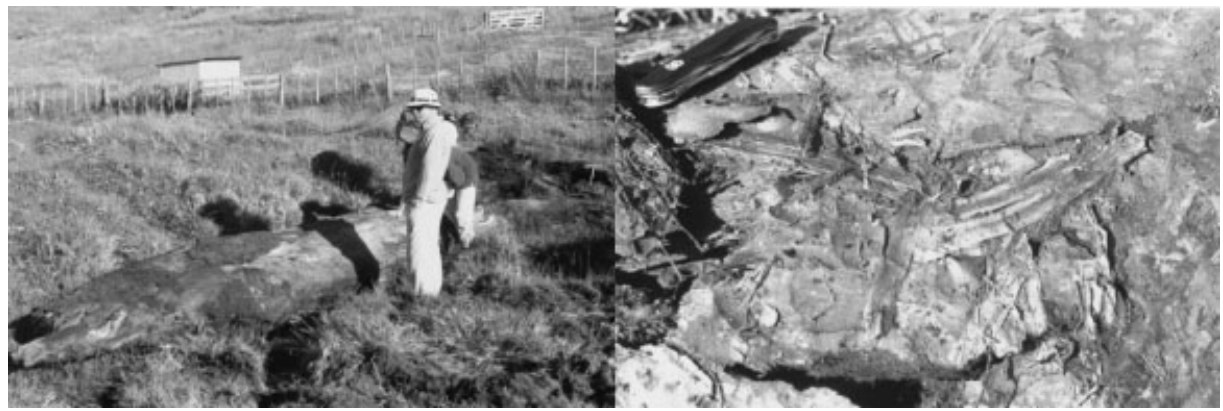

Figure 2 Preserved bark edge subfossil kauri from Robert Harding's farm, near Dargaville

\section{Holocene and OIS 3 kauri site geography}

The majority of ancient kauri sites are located within the dune complex referred to as the North Kaipara Harbour (Sherwood and Schofield, 1985), west of Dargaville on the west coast, and in similar dunes on the Aupouri Peninsula in far Northland (Fig. 1). These dune belts average $8 \mathrm{~km}$ in width and comprise a complex of modern and ancient dunes, fluviatile, lacustrine and estuarine sediments. There appears to have been a number of separate periods of sedimentation during the Quaternary related to changes in sea level and indicated by at least three seams of lignite visible in cliffs along parts of the coastline. Ancient kauri is also located in low-lying coastal areas in close association with long, arcuate sand barrier systems anchored by rocky headlands along the east coast north of Auckland (DSIR, 1973). Low hills under $300 \mathrm{~m}$ elevation with moderate slopes $\left(10-35^{\circ}\right)$ typically back these sites, which are characterised by moist, lowland flats that have commonly been converted to pastureland. On the east coast, the modern barriers fronting OIS 3 kauri sites receive limited sediment from local river catchments primarily from reworked sand (offshore and muddy) and calc-gravelly sand deposits (Carter and Eade, 1980). Local unconsolidated sediment is primarily derived from alluvium and dune sand (Thompson, 1961). The much greater area of AK on the west coast is due to volcanic sediment derived from Mount Taranaki and the Taupo Volcanic Zone via the Waikato River that empties into the Tasman Sea southwest of Auckland, as well as from local sediment sources reworked on shore (Richardson, 1975). The sediment from these sources are moved along the coast by north-moving longshore drift and incorporated into modern west coast barrier systems that front ancient kauri sites.

The late Holocene sites (HK) in the Waikato, and those situated along the eastern edge of the North Kaipara Barrier, are related to aggradational fluvial systems as sea levels rose during the early-mid-Holocene. Where ages are available, the non-marine sediments at these sites are all post-6.5 ka BP, following local sea-level stabilisation (Gibb, 1986). Although recognising some important differences (see later) we regard these late-Holocene sites as analogues for the earlier preservation of kauri at various times during OIS 3.

The connection between drowned fluvial-estuarine systems and preservation of $\mathrm{HK}$ in linked tributary valleys was first recognised close to the Kaihu River near Dargaville (Ogden, pers. comm.). At the Yakkas site (site code YAKK in Fig. 1), stratigraphic studies indicate that estuarine sedimentation in the palaeo-Kaipara Harbour was extensive and rapid, and was subsequently replaced by organic, fresh water sedimentation close to $6 \mathrm{ka}$ BP. Aggradational fluvial features such as palaeo-river terraces observed near the Maitahi site, and relict levees observed up the Kaihu Valley probably resulted from sea-level rise and stabilisation at around the same time in the mid-Holocene (Ogden et al., 1993). At the time of stabilisation, organic fresh water or sub-aerial sedimentation superseded estuarine sedimentation. Subsequently, any kauri communities that were located on nearby hills were then capable of

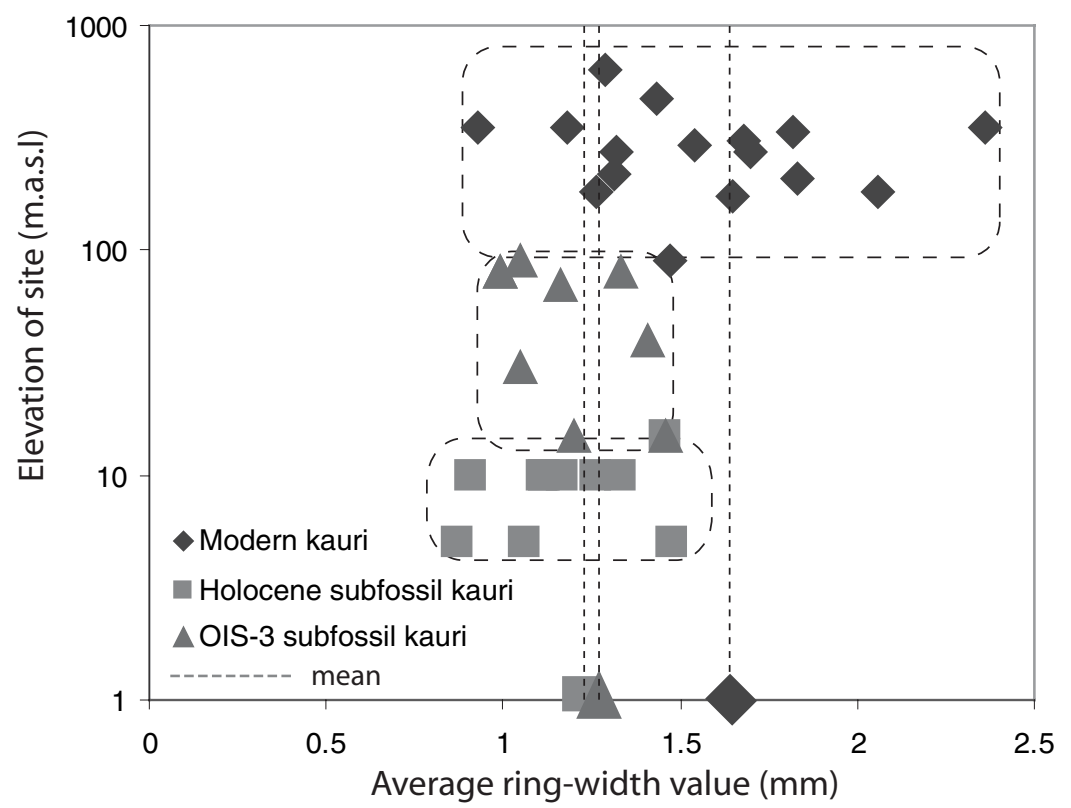

Figure 3 Relative difference between the three collections of kauri sites (i.e. MK, HK and AK) in terms of elevation against average ring-width (ARW) 
colonising lower areas after 6 ka (Ogden et al., 1993), but these areas were probably still prone to periodic flooding. This may help explain suppression and release patterns observed in some associated tree-ring series.

Subfossil kauri sites in the Lake Whangape catchment are connected to the Waikato River system. These subfossil sites were also probably affected by sea-level rise in the late Holocene. Evidence of lake inundation and lake-inlet switching for the Waikato lakes is clear in aerial surveys from the presence of palaeoinlets connected to abandoned bird-foot deltas. Fluvial aggradation and increased sedimentation due to sealevel rise is a likely cause of changing hydrologic conditions within the Lake Whangape catchment, and was probably also enhanced by increased sediment from the Taupo Volcanic Zone (G. Boswijk, pers. comm.). It is possible that hydrologic changes resulting from changes in the Waikato River system may have been imprinted in the kauri tree-rings at these sites.

\section{Methods for collection and analysis of subfossil kauri}

Typically, subfossil kauri logs are extracted from bogs that have been converted to pastureland. Much of the original vegetation was cleared prior to the early 20th century. Many of the bogs have been partially drained and often fires have repeatedly passed over them (McGlone, 1983; Ogden et al., 1998). Site disturbance from kauri gum digging operations in the late 1800s, as well as shrinkage of peat following drainage, resulted in the exposure of buried wood. Despite subaerial erosion as a result of prolonged exposure, many well-preserved logs are still discovered. An example is the Awanui 'staircase' tree that is $3.8 \mathrm{~m}$ in diameter and radiocarbon-dated at greater than $55 \mathrm{ka}$ (Fig. 4).

Our practice has been to work alongside milling companies who use large earth-moving machinery to extract the buried logs. As the logs are extracted, we cut cross-sections or biscuits from the base of the bole but above the root plate to avoid treering distortion because of buttressing and flaring. Subsampling of the cross-sections is needed in order for the rings to be examined and measured under a binocular microscope. Treering samples are prepared and analysed following well-documented dendrochronological techniques for ringwidth measurement and cross-dating (Stokes and Smiley, 1968; Fritts, 1976; Baillie, 1982; Schweingruber, 1988). Fortunately, kauri is relatively long-lived, with most subfossil trees having hundreds of rings. To date, we have collected 167 crosssections from 16 different bog sites and 145 have been measured (Fig. 1, Table 1(c)). At almost every site, at least one cross-section was radiocarbon dated.

\section{Discussion and conclusions}

Dendrochronological and palaeoecological research at ancient kauri sites in Northland was initially undertaken in the early 1980s. Ogden et al. (1992) reviewed 107 radiocarbon-dated subfossil wood samples of Holocene or earlier age. Subsequently, Ogden et al. (1993) used average ring-width data of subfossil kauri in their reconstruction of the general patterns of temperature and rainfall in northern New Zealand, but at that time only one chronology from subfossil kauri wood had been published (Bridge and Ogden, 1986).

As with many palaeoecological studies, radiocarbon dating has been critical to understanding the relative time periods covered by the different tree-ring series. Unfortunately, in this case our samples are close to and sometimes beyond the limits of the radiocarbon-dating technique. Originally it was considered that the rangefinder ages prepared using the traditional acid-base-acid pretreatment method was suitable for all samples. However, it was soon discovered that this was not the case and that in some instances, significant modern contamination remained (in extreme examples, finite radiocarbon ages of $30 \mathrm{ka}$ BP were found to be beyond the limits of the method when the alpha-cellulose component was extracted; Hogg et al., 2006). Shifts of this magnitude in wood had previously not been recognised before and led to the research team having to shift to the more time-expensive alphacellulose extraction and revise their research accordingly. As a result, significant effort has been invested in fully quantifying the radiocarbon backgrounds of alpha-cellulose kauri samples so that precise, finite ages could be obtained (Hogg et al., 2006; Turney et al., 2006). The discovery that traditional pretreatment methods do not remove all contamination in the wood means

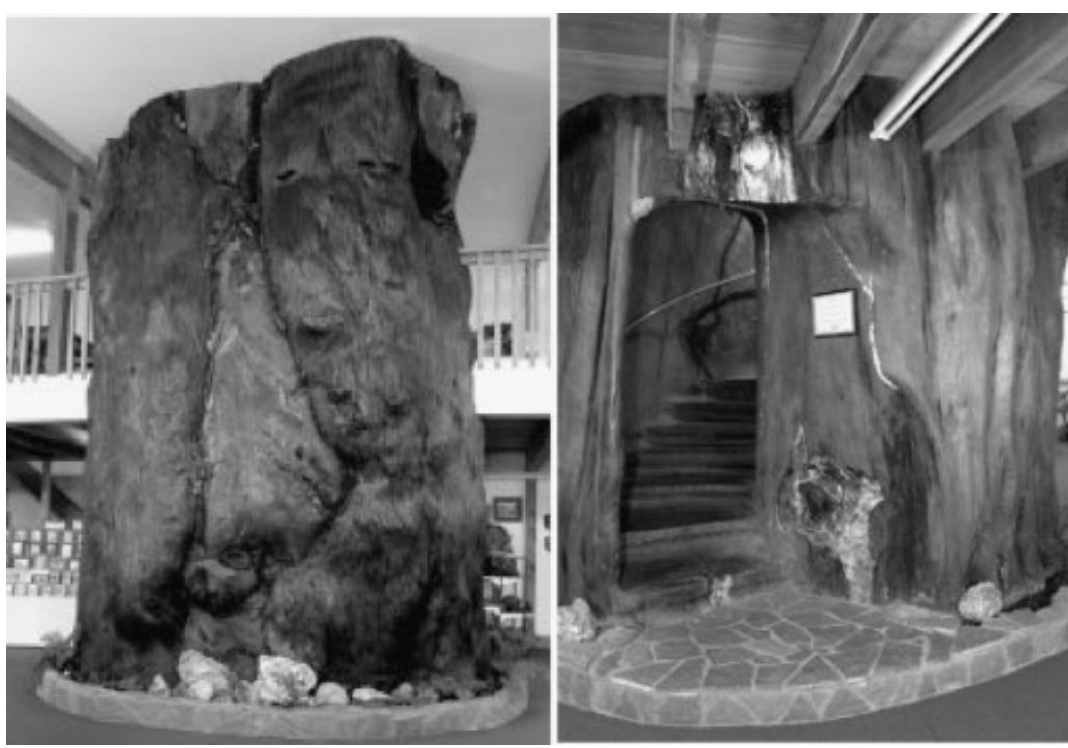

Figure 4 The 'staircase tree' at Ancient Kauri Kingdom, Awanui, Northland, New Zealand 
Number of samples in age classes

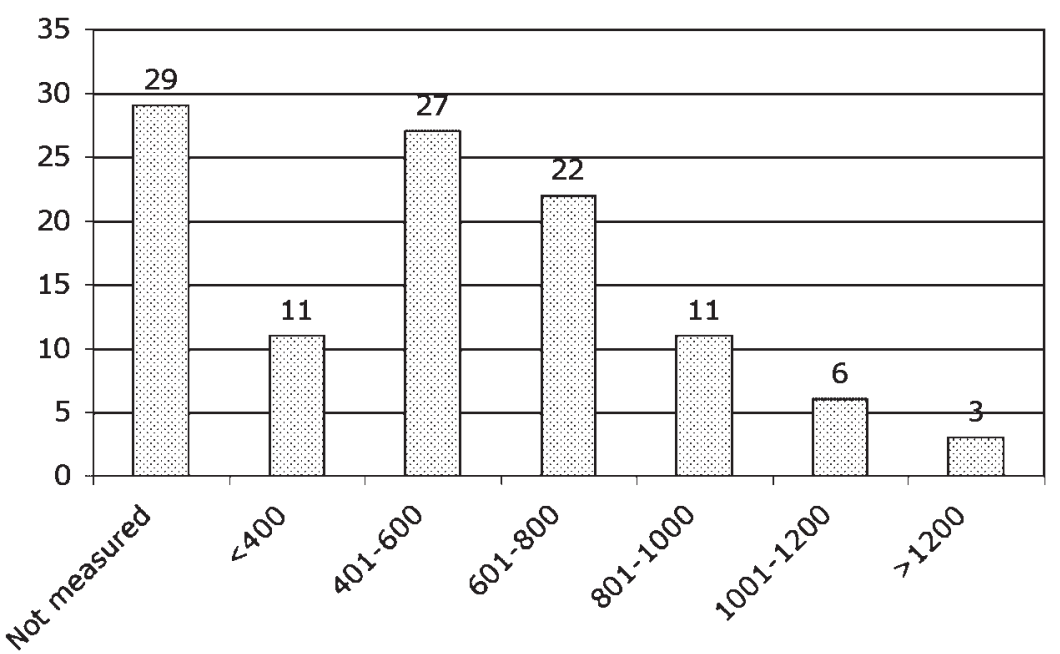

Number of rings

Figure 5 Age-class distribution of OIS 3 kauri tree-ring samples

Table 2 Summary of OIS 3 tree-ring chronologies

\begin{tabular}{lccccc}
\hline Chronology name & Span of years & Number of trees & ARW $(\mathrm{mm})$ & Radiocarbon age (years BP) & External cross-matched series \\
\hline OMAHA1 & 2129 & 22 & 1.34 & ca. $50 \mathrm{ka}$ & \\
OMAHA2 & 1524 & 16 & 1.66 & ca. $33 \mathrm{ka}$ & Finlayson04 $t=8.35 / r=0.41$ \\
OMAHA3 & 853 & 5 & 1.54 & ca. $28.5 \mathrm{ka}$ & \\
OMAHA4 & 1061 & 5 & 0.93 & $>47 \mathrm{ka}$ & Finlayson09 $t=13.67 / r=0.45$ \\
MANG1 & 1410 & 4 & 1.16 & ca. $39 \mathrm{ka}$ & $>35 \mathrm{ka}$ \\
TRIG/VINAC1 & 1342 & 5 & 1.22 & ca. $36 \mathrm{ka}$ & \\
TRIG/VINAC2 & 1230 & 5 & 1.19 & Undated & \\
TRIG/VINAC3 & 1170 & 4 & 1.28 & & \\
Floating temporal coverage & 10719 & & & &
\end{tabular}

that earlier age measurements are open to reinterpretation (e.g. Ogden et al., 1993).

The age structure of the OIS 3 trees from the different sites is shown in Fig. 5 and demonstrates that a wide range of age classes for kauri has been preserved. Mortality was therefore not age-dependent. Possible scenarios for the age range of individuals found at each site could be a circle of encroaching forest trees growing densely around the bog margins (i.e. a successional hydrosere) that were periodically toppled during storm events as a result of enhanced wind-flow (Lorrey and Martin, 2005).

An example of the multi-millennial length tree-ring chronology construction potential for ancient kauri can be gleaned from results of floating chronologies constructed (Table 2, Fig. 6). To date, up to $10719 \mathrm{yr}$ of floating chronology has been replicated. A new site developed at Finlayson's Farm (FIN) has shown that inter-site cross-matching of OIS 3 kauri has great potential for floating kauri site chronologies (Table 2). The intersite cross-matching is impressive because the OIS 3 chronologies are separated by over a hundred kilometres (e.g. MNG and FIN; Table 2). This is consistent with results obtained from modern kauri sites where high inter-site correlations over large separation distances have been described (Ahmed and Ogden, 1985). In the example shown in Fig. 6, five trees from Trig Road (TRIG) and Vinac Farm (VIN) show high $t$-test values and together encompass $1342 \mathrm{yr}$. Furthermore, the spread in the

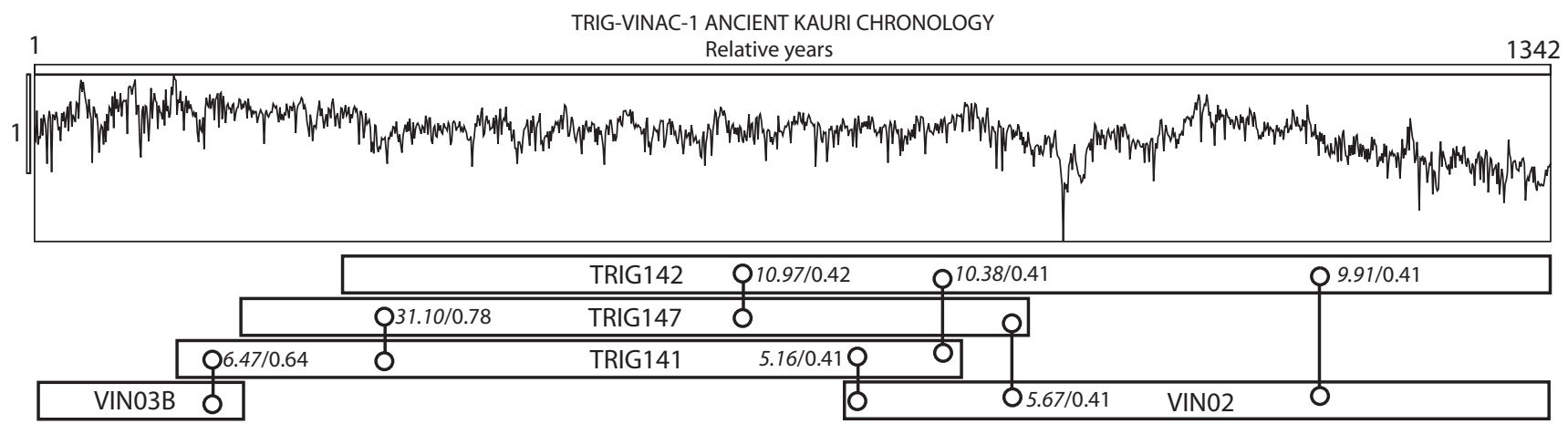

Figure 6 OIS 3 tree-ring chronology and cross-matching between trees from the sites Trig Road and Vinac Farm 
radiocarbon ages obtained from within and between sites indicates that preservation did not take place during one specific period of time. There is therefore considerable potential to develop a continuous tree-ring chronology encompassing all of OIS 3.

The relationship between kauri tree-rings and the SOI (Fowler et al., 2000), and the strong connection to the western pole of the El Nino-Southern Oscillation (ENSO; Fowler, 2005), means there is considerable scope that climatic indices can be successfully reconstructed from OIS 3 kauri at annual resolution over millennial timescales. As a result, records of the atmospheric and ocean circulation interplay between the Australasian and Antarctic sectors could be integrated over tens of thousands of years, and provide important data for global climate models.

The complete lack of any reported OIS 3 tree-ring material from the Northern Hemisphere, and only one published site from the Southern Hemisphere means ancient kauri tree-ring chronologies are some of the oldest, highest-resolution records reported to date. Because the advances in ancient kauri research have primarily been made in the last three years, we consider a continuous kauri chronology spanning tens of thousands of years for OIS 3 is possible within the next decade.

Acknowledgements We would like to acknowledge the support of the local millers and contractors-Dave Stewart, Nelson Parker, Milton Randall, Galvin Frost and Murray Ferris, as well as Albert Lovell and Betty Nelly from the The Kauri Museum (Matakohe). The extensive collection of samples from the Omaha Flats was due to the permission of Tony Gibbs. Technical assistance was provided by Peter Crossley. Anthony Fowler and Gretel Boswijk kindly gave permission to use their data for the comparisons. Funding assistance was provided for various aspects of the research by UK National Environment Research Council Grant \# NER/A/S/2001/01037, New Zealand Marsden Award \# 03UOW-057 and UOA-108, Australian Research Council Grant \# DP0451152 and FRST Grant UOAX0213.

\section{References}

Ahmed M, Ogden J. 1985. Modern New Zealand tree-ring chronologies. 3. Agathis australis (Salib.) - kauri. Tree-Ring Bulletin 45: 11-24.

Baillie MGL. 1982. Tree-ring Dating and Archaeology. The University of Chicago Press: Chicago.

Bond G, Broecker W, Johnsen S, McManus J, Labeyrie L, Jouzel J, Bonani G. 1993. Correlations between climate records from north Atlantic sediments and Greenland ice. Nature 365: 143-147.

Boswijk G, Fowler A, Lorrey A, Palmer J, Ogden J. 2006. Extension of the New Zealand kauri (Agathis australis) chronology to 1724 BC. The Holocene 16: 188-199.

Bradley RS. 1999. Paleoclimatology, Reconstructing Climates of the Quaternary, 2nd edn. Academic Press: San Diego, CA.

Bridge M, Ogden J. 1986. A sub-fossil kauri (Agathis australis) tree-ring chronology. Journal of the Royal Society of New Zealand 16: $17-23$.

Briffa KR, Matthews JA. 2002. ADVANCE-10K: a European contribution towards a hemispheric dendroclimatology for the Holocene. The Holocene 12: 639-642.

Buckley B, Ogden J, Palmer J, Salinger J, Fowler A. 2000. Dendroclimatic interpretation of tree-rings in Agathis australis (kauri) 1. Climate correlation functions and master chronology. Journal of the Royal Society of New Zealand 30: 263-275.

Carter L, Eade JV. 1980. Hauraki sediments. 1:200,000, New Zealand Oceanographic Institution, Coastal Series, Wellington, New Zealand. Clifton NC. 1994. New Zealand Timbers: The Complete Guide to Exotic and Indigenous Woods. GP Publications Ltd: Wellington, New Zealand.
Cook ER, Woodhouse CA, Eakin CM, Meko DM, Stahle DW. 2004. Long-term aridity in the Western United States. Science 306: 10151018.

Cook ER, Buckley BM, Palmer JG, Fenwick P, Peterson MJ, Boswijk G, Fowler A. 2006. Millennia-long tree-ring records from Tasmania and New Zealand: a basis for modelling climate variability and forcing, past, present and future. Journal of Quaternary Science 21: 689-699.

DSIR. 1973. Map 106/1. Parent rocks of New Zealand soils, North Island. 1:1,000,000. NZ Soil Bureau: Wellington.

D'Arrigo R, Wilson R, Palmer J, Krusic P, Curtis A, Sakulich J, Bijaksana S, Zulaikah, S, Ngkoimani LO. 2006. Monsoon drought over Java, Indonesia, during the past two centuries. Geophysical Research Letters 33(4). DOI: 10.1029/2005GL025465.

Dunwiddie P. 1979. Dendrochronological studies of indigenous New Zealand trees. New Zealand Journal of Botany 17: 251266

Fowler AM. 2005. Sea-level pressure composite mapping in dendroclimatology: advocacy and an Agathis australis (kauri) case study. Climate Research 29: 73-84.

Fowler A, Palmer J, Salinger J, Ogden J. 2000. Dendroclimatic interpretation of tree-rings in Agathis australis (kauri): 2. Evidence of a significant relationship with ENSO. Journal of the Royal Society of New Zealand 30: 277-292.

Fowler A, Boswijk G, Ogden J. 2004. Tree-ring studies on Agathis australis (kauri): a synthesis of development work on Late Holocene chronologies. Tree-Ring Research 60: 15-29.

Fritts HC. 1976. Tree Rings and Climate. Academic Press: London.

Gibb JG. 1986. A New Zealand regional eustatic sea level curve and its application to determination of vertical tectonic movements. Royal Society of New Zealand Bulletin 24: 386-393.

Halkett J, Sale EV. 1986. The World of the Kauri. Reed Methuen: Auckland.

Hogg AG, Fifield LK, Palmer JG, Turney CSM, Galbraith R, Robertson S. 2006. Precise radiocarbon age of wood samples by high sensitivity liquid scintillation spectroscopy in the 50-70 ka age range. Radiocarbon (in press).

ITRDB, 2004. http://www.ncdc.noaa.gov/paleo/treering.html [in press 28 March 2006]

Jones PD, Osborn TJ, Briffa KR. 2001. The evolution of climate over the last millennium. Science 292: 662-667.

Lorrey A M, Martin TJ. 2005. Use of modern tree-fall patterns as a guideline for interpreting prostrate trees at a pre-Last Glacial Maximum palaeoforest site, upper North Island, New Zealand. Journal of Geophysical Research-Biogeosciences 110: 1-7.

McGlone M. 1983. Polynesian deforestation of New Zealand: a preliminary synthesis. Archaeology in Oceania 18: 11-25.

Norton DA, Ogden J. 1987. Dendrochronology: a review with emphasis on New Zealand applications. New Zealand Journal of Ecology 10: 77-95.

Ogden J. 1983. The scientific reserves of Auckland University. II. Quantitative vegetation studies. Tane 29: 163-180.

Ogden J, Ahmed M. 1989. Climate response function analyses of kauri (Agathis australis) tree-ring chronologies in northern New Zealand. Journal of the Royal Society of New Zealand 19: 205-221.

Ogden J, Wilson A, Hendy C, Newnham R, Hogg A. 1992. The late Quaternary history of kauri (Agathis australis) in New Zealand and its climatic significance. Journal of Biogeography 19: 611622

Ogden J, Newnham RM, Palmer JG, Serra R, Mitchell ND. 1993. Climatic implications of macro- and micro-fossil assemblages from late Pleistocene deposits in northern New Zealand. Quaternary Research 39: 107-119.

Ogden J, Basher L, McGlone M. 1998. Fire, forest regeneration and links with early human habitation: evidence from New Zealand. Annals of Botany 81: 687-696.

Poole AL, Adams NM. 1986. Trees and Shrubs of New Zealand. Government Printing Office: Wellington, New Zealand.

Reed AH. 1964. The New Story of the Kauri. AH \& AW Reed: Wellington, New Zealand.

Richardson RJH. 1975. The Quaternary geology of the north Kaipara Barrier. MSc thesis, University of Auckland: Auckland, New Zealand. 
Roig FA, Le-Quesne C, Boninsegna JA, Briffa KR, Lara A, Grudd H, Jones PD, Villagrán C. 2001. Climate variability 50,000 years ago in midlatitude Chile as reconstructed from tree rings. Nature 410: 567-570.

Sale EV. 1978. Quest for the Kauri: Forest Giants and Where to Find Them. AH \& AW Reed: Wellington, New Zealand.

Salmon JT. 1980. The Native Trees of New Zealand. Heinemann Reed, Birkenhead: Auckland.

Sarnthein M, Kennett JP, Allen JRM, Berr J, Grootes P, Laj C, McManus J, Ramesh R, SCOR-IMAGES Working Group 117. 2002. Decadal-tomillennial-scale climate variability-chronology and mechanisms: summary and recommendations. Quaternary Science Reviews 21: 1121-112.

Schweingruber FH. 1988. Tree Rings: Basics and Applications of Dendrochronology. Kluwer: The Hague.
Sherwood J, Schofield K. 1985. Lignite deposits of the North Kaipara Harbour, Northland. Department of Scientific Research: Wellington, New Zealand.

Stokes MA, Smiley TL. 1968. An Introduction to Tree-ring Dating. University of Arizona Press: Tucson, AZ.

Thompson RN. 1961. NZ Geologic Map. Whangarei. 1st Edition Sheet 2A. 1:250,000. New Zealand Geological Survey. DSIR: Wellington, New Zealand.

Turney CSM, Fifield LK, Hogg A, Palmer JG, Baillie M. 2006. Radiocarbon age of wood samples during OIS-3 by accelerated mass spectroscopy. Radiocarbon (in press).

Voelker AHL, workshop participants. 2002. Global distribution of centennial-scale records for Marine Isotope Stage (MIS) 3: a database. Quaternary Science Reviews 21: 1185-1212. 